Case Report

\title{
Asymptomatic Congenital Hyperinsulinism due to a Glucokinase-Activating Mutation, Treated as Adrenal Insufficiency for Twelve Years
}

\author{
Kae Morishita, Chika Kyo, Takako Yonemoto, Rieko Kosugi, \\ Tatsuo Ogawa, and Tatsuhide Inoue \\ Center for Diabetes, Endocrinology and Metabolism, Shizuoka General Hospital, No. 4-27-1, Kita-Ando, Aoi-ku, \\ Shizuoka, Shizuoka 420-8527, Japan \\ Correspondence should be addressed to Takako Yonemoto; takakoi@kuhp.kyoto-u.ac.jp
}

Received 15 November 2016; Accepted 21 December 2016; Published 9 January 2017

Academic Editor: John Broom

Copyright (C) 2017 Kae Morishita et al. This is an open access article distributed under the Creative Commons Attribution License, which permits unrestricted use, distribution, and reproduction in any medium, provided the original work is properly cited.

Congenital hyperinsulinism (CHI) caused by a glucokinase- (GCK-) activating mutation shows autosomal dominant inheritance, and its severity ranges from mild to severe. A 43-year-old female with asymptomatic hypoglycemia ( $47 \mathrm{mg} / \mathrm{dL})$ was diagnosed as partial adrenal insufficiency and the administration of hydrocortisone $(10 \mathrm{mg} /$ day $)$ was initiated. Twelve years later, her 8-monthold grandchild was diagnosed with CHI. Heterozygosity of exon 6 c.590T>C (p.M197T) was identified in a gene analysis of GCK, which was also detected in her son and herself. The identification of GCK-activating mutations in hyperinsulinemic hypoglycemia patients may be useful for a deeper understanding of the pathophysiology involved and preventing unnecessary glucocorticoid therapy.

\section{Introduction}

Congenital hyperinsulinism (CHI) is a condition that leads to recurrent hypoglycemia due to the inappropriate secretion of insulin by pancreatic islet $\beta$ cells. Recent developments in gene analyses of CHI-related hypoglycemia have provided detailed information on each mutation detected [1]. Mutations are most frequently detected in the ABCC 8 and KCNJ11 genes, which code for the two KATP-channel subunits SUR1 and Kir6.2, respectively $[2,3]$. Mutations in the glucokinase (GCK), glutamate dehydrogenase (GLUD1), insulin receptor (INSR), hepatocyte nuclear factor 4a (HNF4A), and monocarboxylate transporter 1 (SLC16A1) genes have less commonly been reported to cause $\mathrm{CHI}$ and similar syndromes featuring hyperinsulinemic hypoglycemia [4-8].

Glucokinase (GCK), an enzyme that facilitates the phosphorylation of glucose to glucose-6-phosphate, is an important regulator of glucose homeostasis. GCK has been detected in the pancreas, liver, gut, and brain. In each of these organs, GCK plays an important role in the regulation of carbohydrate metabolism by acting as a glucose sensor in pancreatic $\beta$ cells and promoting the synthesis of glycogen and triglycerides within the liver. A mutation in GCK leads to an inappropriate threshold for glucose-stimulated insulin secretion. Inactivating mutations have been shown to cause maturity-onset diabetes of the young (MODY), whereas activating mutations cause $\mathrm{CHI}$-related hypoglycemia. The activation of glucokinase mutations increases the affinity of glucokinase for glucose and resets the threshold for glucosestimulated insulin secretion. Thus, insulin continues to be produced at lower blood glucose levels. There appears to be little correlation between specific genotypes and the phenotype of GCK-activating mutations; although some case reports have claimed a relationship between severity of the hyperinsulinism and higher relative activity index of the expressed mutant enzyme, the glucose "set point" for most cases appears to be quite stable in a plasma glucose range of $55-65 \mathrm{mg} / \mathrm{dL}$ [9]. Information on the prevalence, natural history, and endocrinological effects of chronic hypoglycemia from GCK mutations is currently limited.

Here we describe the clinical course of GCK-activating mutation, especially focusing on the endocrinological aspects 
TABLE 1: Data of the patient.

\begin{tabular}{lcc}
\hline & First visit & 12 years later \\
\hline Age (years) & 44 & 56 \\
Body weight $(\mathrm{kg})$ & 51 & 54.8 \\
Height $(\mathrm{cm})$ & 148 & 148 \\
BMI & 23.2 & 24.8 \\
Blood pressure (mmHg) & $112 / 72$ & $149 / 88$ \\
Fasting plasma glucose & $52 \mathrm{mg} / \mathrm{dL}$ & $65 \mathrm{mg} / \mathrm{dL}$ \\
Fasting serum insulin $(\mu \mathrm{IU} / \mathrm{mL})$ & $2.8 \mathrm{mmol} / \mathrm{L})$ & $(3.6 \mathrm{mmol} / \mathrm{L})$ \\
HbAlc $(\%)$ & 4.1 & 7.5 \\
Total cholesterol $(\mathrm{mg} / \mathrm{dL})$ & 179 & 4.6 \\
Cortisol $(\mu \mathrm{g} / \mathrm{dL})($ at $8: 00 \mathrm{AM})$ & $6.9-7.9$ & 224 \\
ACTH $(\mathrm{pg} / \mathrm{mL})($ at $8: 00 \mathrm{AM})$ & $23.8-25.2$ & $15.0-21.3$ \\
\hline
\end{tabular}

of chronic hypoglycemia. Identification of this mutation may be essential for preventing erroneous diagnosis, avoiding unnecessary glucocorticoid therapy, and having deeper understanding of the pathophysiology of hyperinsulinemic hypoglycemia.

\section{Case Reports}

The patient was a 56-year-old female. When she was 44 years old, she was referred to our hospital due to asymptomatic hypoglycemia with a plasma glucose level of $47 \mathrm{mg} / \mathrm{dL}$, which was detected in a periodic health examination. Her glucose level at hospitalization was approximately $60 \mathrm{mg} / \mathrm{dL}$ and HbAlc level was 4.1\% (Tables 1 and 2(a)). Neither reactive hypoglycemia nor hyperinsulinemia was detected by the oral glucose tolerance test (OGTT) (Table 2(b)). In the 18hour fasting test, plasma glucose and immunoreactive insulin were $55 \mathrm{mg} / \mathrm{dL}$ and $3.0 \mu \mathrm{IU} / \mathrm{mL}$, respectively, suggesting that insulinoma was unlikely. The insulin tolerance test revealed the suppression of C-peptide as well as the poor responses of ACTH and cortisol (Table 2(c)). Although a circadian variation was maintained in plasma cortisol, her cortisol level in the early morning was slightly low $(6.9 \mu \mathrm{g} / \mathrm{dL})$ (Table 2(d)). The response of cortisol in the rapid ACTH $(250 \mu \mathrm{g})$ stimulation test was at the lower limit of normal (cortisol peaked at $18.4 \geq 18 \mu \mathrm{g} / \mathrm{dL}$ ) [10], while its response in the CRH stimulation test was relatively poor (cortisol peaked at $12.2 \mu \mathrm{g} / \mathrm{dL}$ ) (Tables $2(\mathrm{e})$ and $2(\mathrm{f})$ ). The excretion of 17-hydroxycorticosteroids (17-OHCS) and 17-keto steroids (17-KS) in urine was $2.4 \mathrm{mg} /$ day and $2.5 \mathrm{mg} /$ day, respectively, both of which were below the normal ranges $(2.6-7.8 \mathrm{mg} /$ day and $3.1-8.8 \mathrm{mg} /$ day, resp.). No morphological abnormalities were detected in the adrenal glands, liver, or pancreas on enhanced dynamic CT images. She was diagnosed with hypoglycemia due to partial adrenal insufficiency, and so the administration of hydrocortisone $(10 \mathrm{mg} /$ day $)$ was initiated. Steroid supplementation slightly increased her fasting plasma glucose levels from $52 \mathrm{mg} / \mathrm{dL}$ to $65 \mathrm{mg} / \mathrm{dL}$ and HbAlc levels from $4.1 \%$ to $4.6 \%$. These levels then plateaued for 12 years
(Table 1). Further examinations were not conducted at that time.

Twelve years later, her 8-month-old grandchild was found to be hypoglycemic $(46 \mathrm{mg} / \mathrm{dL})$ while being treated for gastroenteritis. The grandchild's father, the son of our patient, was also diagnosed with asymptomatic hypoglycemia (below $60 \mathrm{mg} / \mathrm{dL}$ ) in a health examination. A family history of asymptomatic hypoglycemia in three generations made the attending doctor of the grandchild suspect GCK-activating mutations. The DNA of her grandchild was analyzed by direct sequencing of the entire coding region and exon-intron boundaries of GCK in Osaka City General Hospital. The heterozygosity of exon 6 c.590T>C (p.M197T), a novel GCK mutation which has already been reported to be an activating mutation in vitro study [11], was identified in her grandson and her son.

CHI due to the same gene mutation was suspected in our patient, and she was hospitalized for a detailed examination when she was 56 years old. Reassessment of glucose diurnal rhythm revealed that her plasma glucose level was $59-83 \mathrm{mg} / \mathrm{dL}$ during the intake of $10 \mathrm{mg}$ of hydrocortisone (Table 3(a)). When our patient decreased and discontinued oral hydrocortisone, her plasma glucose level was definitely lower $(48 \mathrm{mg} / \mathrm{dL})$ but no symptoms were observed (Table 3(a)). The circadian variation in cortisol was maintained without any intake of hydrocortisone (Table 3(b)). Although her basal cortisol level was relatively low $(4.5-8.8 \mu \mathrm{g} / \mathrm{dL})$, cortisol responses to the ACTH and $\mathrm{CRH}$ stimulation tests were within the normal ranges; peaks in serum cortisol were observed at $24.5 \mu \mathrm{g} / \mathrm{dL}$ and $15.8 \mu \mathrm{g} / \mathrm{dL}$, respectively (Tables $3(\mathrm{c})$ and $3(\mathrm{~d})$ ).

After obtaining written informed consent, a GCK gene analysis was conducted. The sequencing of exon 6 in her DNA revealed the same mutation as her son and grandchild, and she was diagnosed with congenital hyperinsulinemic hypoglycemia (Figure 1). Since there seems to be no correlation between genotype and phenotype of GCK mutation, we were unable to estimate the severity of hypoglycemia according to the mutation site $[9,12]$. However, the severity of hypoglycemia was classified as mild based on her physical and mental states at the age of 43 in the absence of any treatment. Therefore, we decided to stop prescribing hydrocortisone. A favorable course has been followed for several years after the discontinuation of oral hydrocortisone.

\section{Discussion}

We encountered a family with $\mathrm{CHI}$ due to a novel mutation in GCK, with an 8-month-old infant as the index case. This GCK mutation itself has already been reported previously as a case report of the grandson [13]. We demonstrated here endocrinological aspects before and after steroid treatment in the patient with GCK-activating mutation, suggesting when and how we should suspect the GCK mutation as differential diagnoses of hypoglycemia.

Glucokinase-activating mutations result in hyperinsulinemic hypoglycemia. The diagnosis and treatment of hyperinsulinemic hypoglycemia have markedly advanced in recent 
TABLE 2: Results of examinations at first visit.

(a) Glucose diurnal rhythm.

\begin{tabular}{|c|c|c|c|c|c|c|c|}
\hline Clock time & $7: 30$ & $10: 00$ & $11: 30$ & $14: 00$ & $17: 30$ & $20: 00$ & 23:00 \\
\hline \multicolumn{8}{|c|}{ Plasma glucose } \\
\hline$(\mathrm{mg} / \mathrm{dL})$ & 57 & 59 & 62 & 64 & 61 & 84 & 64 \\
\hline$(\mathrm{mmol} / \mathrm{L})$ & 3.1 & 3.2 & 3.4 & 3.5 & 3.3 & 4.6 & 3.5 \\
\hline
\end{tabular}

(b) OGTT (oral glucose tolerance test) performed with $75 \mathrm{~g}$ glucose.

\begin{tabular}{|c|c|c|c|c|c|}
\hline Time (min) & 0 & 30 & 60 & 90 & 120 \\
\hline \multicolumn{6}{|l|}{ Plasma glucose } \\
\hline$(\mathrm{mg} / \mathrm{dL})$ & 62 & 119 & 120 & 84 & 75 \\
\hline$(\mathrm{mmol} / \mathrm{L})$ & 3.4 & 6.6 & 6.6 & 4.6 & 4.1 \\
\hline Insulin $(\mu \mathrm{U} / \mathrm{mL})$ & 2.0 & 24.3 & 45.5 & 38 & 17.9 \\
\hline
\end{tabular}

(c) Plasma glucose, c-peptide, glucagon, cortisol, and ACTH responses to insulin tolerance test (0.05 U/kg BW of Humulin R).

\begin{tabular}{|c|c|c|c|c|c|c|c|c|}
\hline Time (min) & 0 & 15 & 30 & 45 & 60 & 75 & 90 & 120 \\
\hline \multicolumn{9}{|l|}{ Plasma glucose } \\
\hline$(\mathrm{mg} / \mathrm{dL})$ & 53 & 36 & 30 & 48 & 55 & 53 & 52 & 53 \\
\hline$(\mathrm{mmol} / \mathrm{L})$ & 2.9 & 2.0 & 1.6 & 2.6 & 3.0 & 2.9 & 2.8 & 2.9 \\
\hline C-peptide (ng/mL) & 1.2 & 0.7 & 0.5 & 0.5 & 0.5 & 0.4 & 0.4 & 0.5 \\
\hline Glucagon (pg/mL) & 213 & 230 & 297 & 232 & 207 & 174 & & 174 \\
\hline ACTH (pg/mL) & 40 & 32.8 & 41.3 & 42.4 & 29.5 & 24.4 & 17.2 & 20.1 \\
\hline Cortisol ( $\mu \mathrm{g} / \mathrm{dL})$ & 6.6 & 13.2 & 12 & 15 & 12.8 & 11.9 & 11.2 & 8.4 \\
\hline
\end{tabular}

Normal values.

Glucagon 70-174 (pg/mL), ACTH: 7.2-63.3 (pg/mL), and cortisol: 8.0-18.0 ( $\mu \mathrm{g} / \mathrm{dL})$.

Interpretation of results.

The normal peak ACTH value poststimulation should be an increment no less than $50 \mathrm{pg} / \mathrm{mL}$ at $60^{\prime}$. Baseline cortisol values $<5 \mu \mathrm{g} / \mathrm{dL}$ are diagnostic of adrenal insufficiency. The normal peak cortisol value poststimulation should be an increment no less than $7 \mu \mathrm{g} / \mathrm{dL}$ and a maximal level $>20 \mu \mathrm{g} / \mathrm{dL}$ at $30^{\prime}$.

(d) Circadian variation in cortisol.

\begin{tabular}{lccc}
\hline Clock time & $8: 00$ & $17: 00$ & $23: 00$ \\
ACTH $(\mathrm{pg} / \mathrm{mL})$ & 23.8 & 14.3 & 14.5 \\
Cortisol $(\mu \mathrm{g} / \mathrm{dL})$ & 6.9 & 2.0 & $>1.0$ \\
\hline
\end{tabular}

(e) Cortisol response to the rapid ACTH stimulation test ( $250 \mu \mathrm{g}$, intravenous bolus).

\begin{tabular}{lccc}
\hline Time $(\min )$ & 0 & 30 & 60 \\
Cortisol $(\mu \mathrm{g} / \mathrm{dL})$ & 7.9 & 16.5 & 18.4 \\
\hline
\end{tabular}

Interpretation of results.

The normal peak cortisol value poststimulation should be an increment no less than $18 \mu \mathrm{g} / \mathrm{dL}$.

(f) Cortisol and ACTH responses to the CRH stimulation test (100 $\mu \mathrm{g}$, intravenous bolus).

\begin{tabular}{lcccccc}
\hline Time $(\mathrm{min})$ & 0 & 15 & 30 & 60 & 90 & 120 \\
ACTH $(\mathrm{pg} / \mathrm{mL})$ & 35.2 & 49.3 & 54.6 & 54 & 37.8 \\
Cortisol $(\mu \mathrm{g} / \mathrm{dL})$ & 10.4 & 11.4 & 12.2 & 12.2 & 11.9 & 1.4 \\
\hline
\end{tabular}

Interpretation of results.

The normal peak ACTH value poststimulation should be an increment no less than $20 \mathrm{pg} / \mathrm{mL}$. Cortisol should be an increment no less than $5 \mu \mathrm{g} / \mathrm{dL}$.

years [14]. Severe hypoglycemia in infancy causes neurological dysfunctions and requires appropriate management. On the other hand, some cases of congenital hyperinsulinism are mild and overlooked until adulthood [15]. CHI related to a GCK-activating mutation was suspected in this case due to the presence of autosomal dominant inheritance and hyperinsulinism, with her blood glucose level being relatively low without symptoms. Difficulties are often associated with diagnosing $\mathrm{CHI}$ because, as in this case, some cases not accompanied by hyperinsulinemic hypoglycemia even though GCK gene mutations are present [12].

Glucokinase is a key regulatory enzyme in pancreatic $\beta$-cells. It phosphorylates glucose as a second substrate to form glucose-6-phosphate (G6P) as a first step in the glycolytic pathway. Since it plays a crucial role in the regulation of insulin secretion and is termed the glucose sensor in pancreatic $\beta$-cells, it is understandable that a mutation in GCK leads to an inappropriate threshold for 
TABLE 3: Results of examinations on the patient after 12 years.

(a) Glucose diurnal rhythm

\begin{tabular}{|c|c|c|c|c|c|}
\hline Clock time & $7: 30$ & $11: 30$ & $17: 30$ & $20: 00$ & $23: 00$ \\
\hline \multicolumn{6}{|c|}{ Plasma glucose } \\
\hline \multicolumn{6}{|c|}{$10 \mathrm{mg}$ hydrocortisone $(8: 00)$} \\
\hline$(\mathrm{mg} / \mathrm{dL})$ & 63 & 80 & 59 & 83 & 81 \\
\hline$(\mathrm{mmol} / \mathrm{L})$ & 3.5 & 4.4 & 3.2 & 4.6 & 4.5 \\
\hline \multicolumn{6}{|c|}{$5 \mathrm{mg}$ hydrocortisone $(8: 00)$} \\
\hline$(\mathrm{mg} / \mathrm{dL})$ & 58 & 68 & 67 & 84 & 80 \\
\hline$(\mathrm{mmol} / \mathrm{L})$ & 3.2 & 3.7 & 3.7 & 4.6 & 4.4 \\
\hline \multicolumn{6}{|c|}{ no hydrocortisone } \\
\hline$(\mathrm{mg} / \mathrm{dL})$ & 48 & 64 & 57 & 77 & 67 \\
\hline$(\mathrm{mmol} / \mathrm{L})$ & 2.6 & 3.5 & 3.1 & 4.2 & 3.7 \\
\hline
\end{tabular}

(b) Circadian variation in cortisol.

\begin{tabular}{lccc}
\hline Clock Time & $8: 00$ & $17: 00$ & $23: 00$ \\
ACTH $(\mathrm{pg} / \mathrm{mL})$ & 21.3 & 10.2 & 8.3 \\
Cortisol $(\mu \mathrm{g} / \mathrm{dL})$ & 8.8 & 2.8 & 1.1 \\
\hline
\end{tabular}

(c) Cortisol response to the ACTH rapid stimulation test ( $250 \mu \mathrm{g}$, intravenous bolus).

\begin{tabular}{lccc}
\hline Time $(\min )$ & 0 & 30 & 60 \\
Cortisol $(\mu \mathrm{g} / \mathrm{dL})$ & 6.8 & 22.2 & 24.5 \\
\hline
\end{tabular}

Interpretation of results.

The normal peak cortisol value poststimulation should be an increment no less than $18 \mu \mathrm{g} / \mathrm{dL}$.

(d) Cortisol and ACTH responses to the $\mathrm{CRH}$ stimulation test (100 $\mu \mathrm{g}$, intravenous bolus).

\begin{tabular}{lcccccc}
\hline Time $(\mathrm{min})$ & 0 & 15 & 30 & 60 & 90 & 120 \\
$\mathrm{ACTH}(\mathrm{pg} / \mathrm{mL})$ & 15 & 62.8 & 75.3 & 53.6 & 38 & 33.8 \\
Cortisol $(\mu \mathrm{g} / \mathrm{dL})$ & 4.5 & 9 & 15.8 & 15.5 & 13 & 12.6 \\
\hline
\end{tabular}

Interpretation of results.

The normal peak ACTH value poststimulation should be an increment no less than $20 \mathrm{pg} / \mathrm{mL}$. Cortisol should be an increment no less than $5 \mu \mathrm{g} / \mathrm{dL}$.

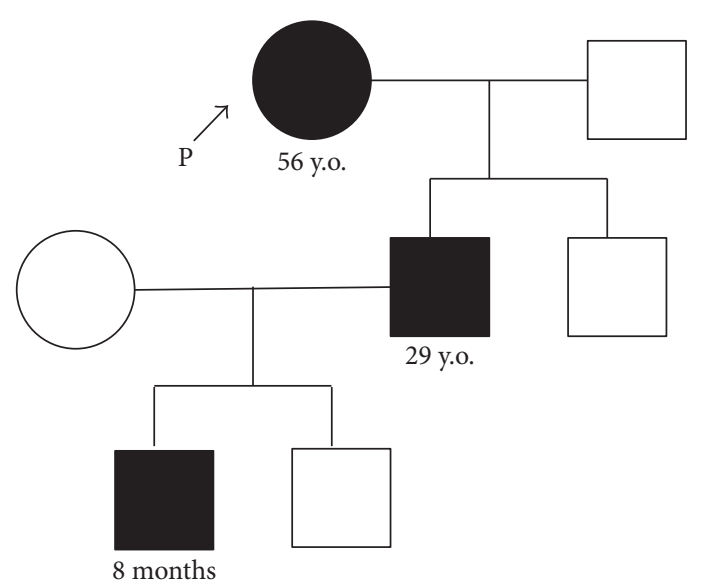

(a)
GCK exon 6
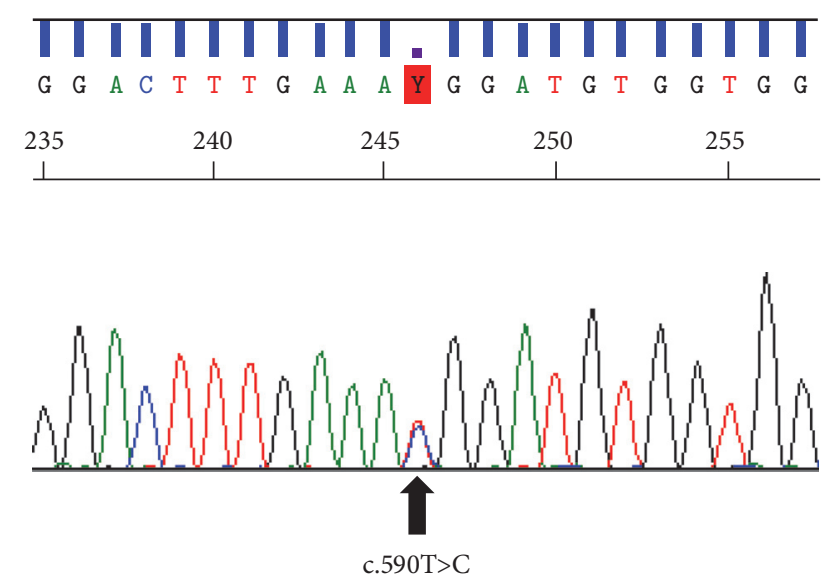

(b)

FIgUre 1: (a) Pedigree tree of the patient. (b) GCK gene analysis of the patient (grandmother). The heterozygosity of exon 6 c.590T>C (p.M197T), a novel GCK-activating mutation, was identified. 
glucose-stimulated insulin secretion. A glucokinaseactivating mutation is one of the rare variants of congenital hyperinsulinism (CHI), and only 12 activating GCK mutations have been described and identified in 8 families and 7 individuals to date [12]. GCK gene mutations have been associated with various grades of symptoms such that many mild cases may be left undiagnosed until adulthood [16]. No criteria currently exist for the treatment of asymptomatic CHI.

A gene analysis involving GCK needs to be conducted when hypoglycemia with an unknown etiology is encountered. Although a family history is very important, there may be cases of new unnoticed-familial mutations. Information on genetic mutations, except for GCK, generally assists in predicting prognoses and responses to $\mathrm{CHI}$ treatments. In contrast, since the GCK mutation in the same family had a variety of phenotypes, we were unable to estimate the severity of hypoglycemia based on the mutation site [12]. It should be noted that our patient did not have any difficulties with stressful events, such as the delivery of her son, without any treatment. Therefore, the lower set point of hypoglycemia in our patient was not expected to become a serious problem throughout the rest of her life.

Our patient had been taking hydrocortisone for 12 years based on her poor response to the CRH stimulation test. According to previous findings on patients not only with diabetes [17, 18], but also without diabetes [19], hypoglycemia attenuated sympathoadrenal responses to declining plasma glucose concentrations, leading to hypoglycemia-associated autonomic failure (HAAF). Chronic hypoglycemia due to a GCK mutation may influence cortisol responses. Recent studies suggested that glucokinase in the hypothalamus and hindbrain participated in the activation of the norepinephrine and epinephrine neurons needed for the counterregulatory response $[20,21]$. We speculated that not only HAAF but also a glucose sensing abnormality due to the activation of glucokinase in neuronal cells accounted for the counterregulatory hormone levels (basal and responses) of our patient.

An overdose of steroids is associated with a risk of side effects, including weight gain, hypertension, hyperlipidemia, and, sometimes, suppression of the HPA axis. Actually, her body weight increased by $3.8 \mathrm{~kg}$ (BMI: from 23.2 to 24.8 ) and blood pressure elevated $(112 / 72 \mathrm{mmHg}$ to $149 / 88 \mathrm{mmHg}$ ) during the 12-year treatment (Table 1). Two months after discontinuation of steroids, she had lost $1.8 \mathrm{~kg}$ in weight and her blood pressure decreased to $125 / 80 \mathrm{mmHg}$. Though $10 \mathrm{mg}$ of oral hydrocortisone is within the physiological range, her circadian variation of cortisol must have been unnatural [22]. Considering these facts, $10 \mathrm{mg}$ of oral hydrocortisone probably bears some responsibility with weight gain and hypertension.

In conclusion, the identification of GCK-activating mutations in hyperinsulinemic hypoglycemia patients may be useful for a deeper understanding of the pathophysiology involved and preventing unnecessary glucocorticoid therapy. More precise interpretations are needed while treating hypoglycemia and adrenal dysfunction.

\section{Competing Interests}

None of the authors have any potential conflict of interests associated with this work.

\section{Authors' Contributions}

Kae Morishita and Chika Kyo contributed equally to this work.

\section{Acknowledgments}

The authors sincerely thank Dr. Tohru Yorifuji (Department of Pediatric Endocrinology and Metabolism, Children's Medical Center, Osaka City General Hospital, Osaka, Japan) for analyzing the GCK mutation. The authors also thank Dr. Kenji Nanao (Department of Pediatrics, Hino Municipal Hospital, Tokyo, Japan), the doctor of the subject's grandchild, for his kind advice.

\section{References}

[1] C. A. Stanley, "Perspective on the genetics and diagnosis of congenital hyperinsulinism disorders," Journal of Clinical Endocrinology and Metabolism, vol. 101, no. 3, pp. 815-826, 2016.

[2] P. M. Thomas, G. J. Cote, N. Wohllk et al., "Mutations in the sulfonylurea receptor gene in familial persistent hyperinsulinemic hypoglycemia of infancy," Science, vol. 268, no. 5209, pp. 426429, 1995.

[3] P. Thomas, Y. Ye, and E. Lightner, "Mutation of the pancreatic islet inward rectifier Kir6.2 also leads to familial persistent hyperinsulinemic hypoglycemia of infancy," Human Molecular Genetics, vol. 5, no. 11, pp. 1809-1812, 1996.

[4] B. Glaser, P. Kesavan, M. Heyman et al., "Familial hyperinsulinism caused by an activating glucokinase mutation," New England Journal of Medicine, vol. 338, no. 4, pp. 226-230, 1998.

[5] C. A. Stanley, Y. K. Lieu, B. Y. L. Hsu et al., "Hyperinsulinism and hyperammonemia in infants with regulatory mutations of the glutamate dehydrogenase gene," New England Journal of Medicine, vol. 338, no. 19, pp. 1352-1357, 1998.

[6] K. Højlund, T. Hansen, M. Lajer et al., "A novel syndrome of autosomal-dominant hyperinsulinemic hypoglycemia linked to a mutation in the human insulin receptor gene," Diabetes, vol. 53, no. 6, pp. 1592-1598, 2004.

[7] E. R. Pearson, S. F. Boj, A. M. Steele et al., "Macrosomia and hyperinsulinaemic hypoglycaemia in patients with heterozygous mutations in the HNF4A gene," PLoS Medicine, vol. 4, no. 4, article no. el18, 2007.

[8] T. Otonkoski, H. Jiao, N. Kaminen-Ahola et al., "Physical exercise-induced hypoglycemia caused by failed silencing of monocarboxylate transporter 1 in pancreatic $\beta$ cells," The American Journal of Human Genetics, vol. 81, no. 3, pp. 467-474, 2007.

[9] D. D. Deleon and C. A. Stanley, Eds., Monogenic Hyperinsulinemic Hypoglycemia Disorders. Frontiers in Diabetes, Karger, Geneva, Swizerland, 2012.

[10] The Japan Endocrine Society, "Guideline of management and treatment of adrenal insufficiency," 2014 (Japanese), http:// square.umin.ac.jp/endocrine/hottopics/20140311sinryousisin .pdf. 
[11] S. Sayed, D. R. Langdon, S. Odili et al., "Extremes of clinical and enzymatic phenotypes in children with hyperinsulinism caused by glucokinase activating mutations," Diabetes, vol. 58, no. 6, pp. 1419-1427, 2009.

[12] T. Meissner, J. Marquard, N. Cobo-Vuilleumier et al., "Diagnostic difficulties in glucokinase hyperinsulinism," Hormone and Metabolic Research, vol. 41, no. 4, pp. 320-326, 2009.

[13] K. Nanao, T. Yorifuji, T. Kamimaki et al., "Congenital hyperinsulinism in a Japanese family with a novel heterozygous GCK mutation," Clinical Endocrinology, vol. 59, pp. 1049-1051, 2011 (Japanese).

[14] T. Yorifuji, M. Masue, and H. Nishibori, "Congenital hyperinsulinism: global and Japanese perspectives," Pediatrics International, vol. 56, no. 4, pp. 467-476, 2014.

[15] K. K. Osbak, K. Colclough, C. Saint-Martin et al., "Update on mutations in glucokinase $(G C K)$, which cause maturityonset diabetes of the young, permanent neonatal diabetes, and hyperinsulinemic hypoglycemia," Human Mutation, vol. 30, no. 11, pp. 1512-1526, 2009.

[16] J. Marquard, A. A. Palladino, C. A. Stanley, E. Mayatepek, and T. Meissner, "Rare forms of congenital hyperinsulinism," Seminars in Pediatric Surgery, vol. 20, no. 1, pp. 38-44, 2011.

[17] A. L. Cuesta-Muñoz, H. Huopio, T. Otonkoski et al., "Severe persistent hyperinsulinemic hypoglycemia due to a de novo glucokinase mutation," Diabetes, vol. 53, no. 8, pp. 2164-2168, 2004.

[18] P. E. Cryer, "Mechanisms of hypoglycemia-associated autonomic failure in diabetes," New England Journal of Medicine, vol. 369, no. 4, pp. 362-372, 2013.

[19] S. Mathur, J. Boparai, S. N. Mediwala et al., "Reversible Adrenal insufficiency in three patients with Post-Roux-en-Y gastric bypass noninsulinoma pancreatogenous hypoglycemia syndrome," Journal of Investigative Medicine High Impact Case Reports, pp. 1-6, 2014.

[20] L. Zhou, C.-Y. Yueh, D. D. Lam et al., "Glucokinase inhibitor glucosamine stimulates feeding and activates hypothalamic neuropeptide Y and orexin neurons," Behavioural Brain Research, vol. 222, no. 1, pp. 274-278, 2011.

[21] J. Zhou, D. S. Roane, X. Xi et al., "Short-term food restriction and refeeding alter expression of genes likely involved in brain glucosensing," Experimental Biology and Medicine, vol. 228, no. 8, pp. 943-950, 2003.

[22] S. Hahner and B. Allolio, "Management of adrenal insufficiency in different clinical settings," Expert Opinion on Pharmacotherapy, vol. 6, no. 14, pp. 2407-2417, 2005. 


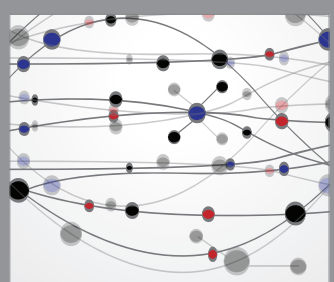

The Scientific World Journal
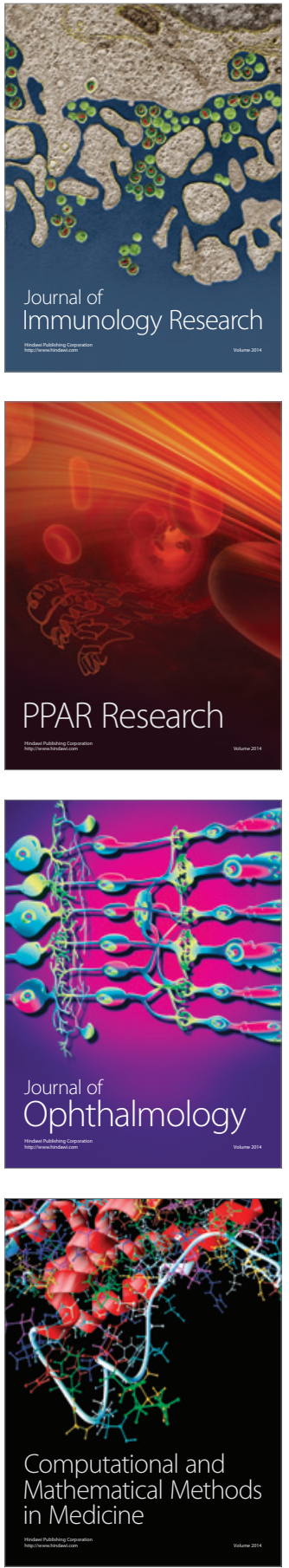

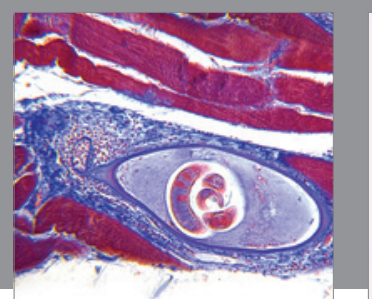

Gastroenterology Research and Practice
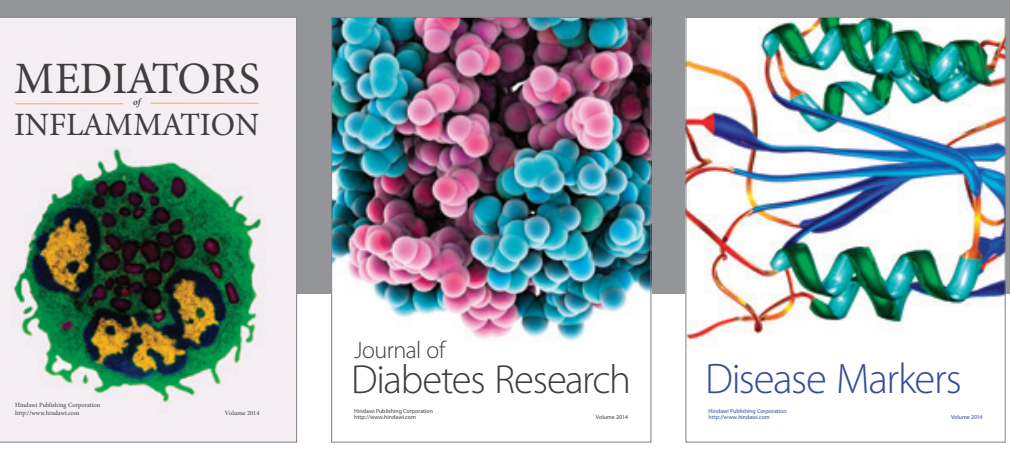

Disease Markers

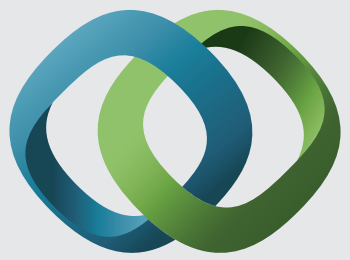

\section{Hindawi}

Submit your manuscripts at

https://www.hindawi.com
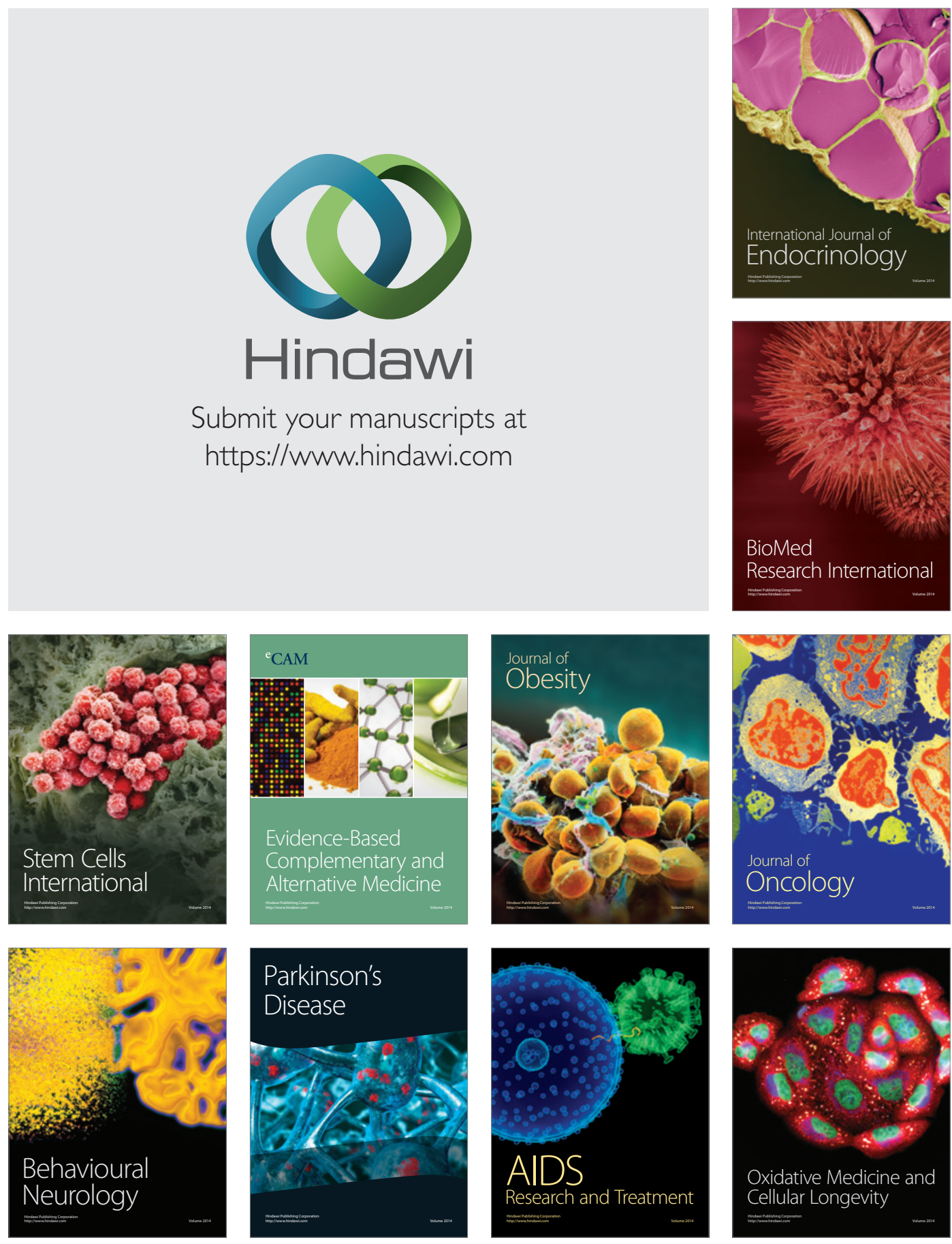